\title{
Comparative Study of Different Preservative Solutions for Extending Flower Quality and Market Acceptability of Rosa bybrida Cv. Freedom
}

\author{
Muhammad Ahsan ${ }^{1 *}$, Aneela Ramzan ${ }^{1}$, Muhammad Nafees ${ }^{1}$, Adnan Younis ${ }^{2}$, Muhammad Amin ${ }^{1}$, Gulzar \\ Akhtar $^{3}$, Khansa Saleem ${ }^{1}$ and Azka Sabeeh ${ }^{1}$
}

${ }^{1}$ Department of Horticultural Sciences, Faculty of Agriculture and Environmental Sciences, The Islamia University of Bahawalpur, Pakistan; ${ }^{2}$ Institute of Horticultural Sciences, University of Agriculture Faisalabad, Pakistan; ${ }^{3}$ Department of Horticulture, Muhammad Nawaz Shareef University of Agriculture, Multan, Pakistan.

\begin{abstract}
Amongst all the floricultural crop, Rose is one of the most important crop both economically as well as aesthetically whose beauty must be enjoyed for longer period of life. Current experiment was performed to discover the comparative consequence of various vase solutions to improve the post-harvest qualities and extend vase life of Rosa bybrida cv. Freedom. The research was performed at the research area of Department of Horticultural Sciences, The Islamia University of Bahawalpur. There were 11 treatments comprising of honey $\left(\mathrm{T}_{1}\right)$, sugar $\left(\mathrm{T}_{2}\right)$, salicylic acid $\left(\mathrm{T}_{3}\right)$, acetic acid $\left(\mathrm{T}_{4}\right)$, indole acetic acid (IAA) $\left(\mathrm{T}_{5}\right)$ and combination of all solutions with sugar. These treatments were compared with tap water $\left(\mathrm{T}_{0}\right)$. There were four plants in each treatment with three replications which were arranged according to completely randomized design (CRD) under room temperature. The results showed that maximum fresh weight (g) was obtained in $\mathrm{T}_{4}$ (acetic acid), flower head diameter $(\mathrm{mm})$ and flower color was ideal under $\mathrm{T}_{3}$ (salicylic acid). Maximum dry weight $(\mathrm{g})$, highest flower freshness on $1^{\text {st }}$ and $3^{\text {rd }}$ day, minimum petal discoloration which leads to productive market acceptability and highest vase life was recorded in $\mathrm{T}_{2}$ (sugar). It is worth to note that lowest market acceptability of flower was observed when sugar is combined with other solution especially IAA. It means sugar reduces its effectiveness when combined with growth regulators. From this experiment, it can be concluded that sugar $\left(\mathrm{T}_{2}\right)$ provide ideal medium for enhancing the post-harvest attributes of Rosa bybrida cv. Freedom.
\end{abstract}

Received | December 02, 2020; Accepted | March 15, 2021; Published | June 22, 2021

*Correspondence | Muhammad Ahsan, Department of Horticultural Sciences, Faculty of Agriculture and Environmental Sciences, The Islamia University of Bahawalpur, Pakistan; Email: ahsan.horti@iub.edu.pk

Citation | Ahsan, M., A. Ramzan, M. Nafees, A. Younis, M. Amin, G. Akhtar, K. Saleem and A. Sabeeh. 2021. Comparative study of different preservative solutions for extending flower quality and market acceptability of Rosa hybrida Cv. freedom. Pakistan Journal of Agricultural Research, 34(3): 545-551.

DOI | https://dx.doi.org/10.17582/journal.pjar/2021/34.3.545.551

Keywords | Acetic acid, Cut flower, Honey, Post-harvest, Roses, Salicylic acid

\section{Introduction}

$\mathrm{R}$ oses (Rosa bybrida) belong to the genus Rosa and Rosaceae family that contains more than 2000 varieties throughout the world (Ahsan et al., 2017). Among these 2000 varieties, many of the species are used as cut flowers, indoor and outdoor decorations and for food preparation (Younis et al., 2013). Roses are at the top in the cut flower industry and exemplify a tremendous commercial cultivar throughout the world (Fanourakisa et al., 2013). From medicinal and nutritional perspective roses are of great importance. In the built-up of different products of medicinal and nutritional importance roses plays a vital role. Similarly, rose plant production is also a great initiative to promote cut flower business as well as 
floriculture industry (Butt, 2005). The permanence in the cut flower life can be increased by using the vase life extending solutions. Addition of carbohydrates in the solution create negative environment for the flower and ultimately result in the form of loss of petal color and overcome the increased bud blasting (Susan, 2003). Cut flowers especially roses have shorter vase life. Just beneath the floral head both flowers and their axis bent down (Van Doorn et al., 1997). These indications are due to vascular obstruction, which prevent liquid uptake in the flowers (Loubaud and Van Doorn, 2004). The most important aim of advancing in postharvest science on the road to provide statistics for the floricultural industry which helps to provide consumers with attention-grabbing, enduring and beautiful cut flowers (Scariot et al., 2014).

It is well known that blockage of xylem vessels is the main reason of rose vase life reduction (Van Meetern et al., 2000). Stumbling block of flower stems may occur as a result of vase solution microorganism (Loubaud and Van Doorn, 2004; He et al., 2006), ventilation blockade (Van Lepern, 2007) and the anatomical damage healing (Williamson et al., 2002). Various techniques have discovered to boost the postharvest life of flowers especially cut flowers to keep them fresh for a longer period of time (Elgimabi, 2011). Carbohydrates in the form of sugar and disinfectants in the form of germicide are the two main constituents used as vase solution. Sugar helps the flowers in respiration and germicides help to prevent bacterial attack on the conducting tissues of the flowers (Zencirkiran, 2010). Pulsing with different concentrations of sugar is very effective method in boosting-up the post-harvest life different flowers (Elgimabi, 2011). Studies showed that addition of sugar in the form of sucrose enhance the lastingness of many cut flowers, because sucrose provide a healthy diet to the flower tissues carbohydrates starvation, flowers blooming and subsequent $\mathrm{H}_{2} \mathrm{O}$ uptake (Hayat et al., 2009). Defoliating effect of petal color in cut flowers is suppressed by adding sugars to the vase solution and overcome the increased bud blasting (Susan, 2003). The use of $125 \mathrm{mgL}-1$ salicylic acid the vase life was significantly extended (Fariba et al., 2012). Different chemical combinations with sucrose increase the post-harvest life of cut flowers and their physiological characteristics including flower size and vascular tissues (Shirin and Mohsen, 2011). Considering the above facts the current study was performed to detect the appropriate preserving mixture in order to extend the vase life of cut roses.

Salicylic acid, a plant hormone has diverse role in physiological and biological process of plants (Hayat et al., 2009). The word Salicylic acid (SA) was derived from Latin word "Salix", meaning willow tree (Raskin et al., 1990). SA is assigned contrasting regulatory rules in the metabolism of plants actually phenolic help to synchronize the plant metabolic activities (Shakirova et al., 2003), playing a role as a natural indicator of thermogenesis not also enhance the bud initiation in plants but also improve the physiological characteristics of plant including water and mineral uptake by roots and stomatal opening in leaves (Raskin, 1992) moreover, it also point to regulation of genes expression in the course of leaf aging (Morris et al., 2000). SA and sucrose addition in vase solution of roses has significantly reduced the respiration rate, alleviated humidity and improve post-harvest life of cut roses (Bayat et al., 2013). Besides, SA treatment is useful in enhancing the post-harvest life of many cut flowers especially roses (Hayat et al., 2009). Indole acetic acid (IAA) is a naturally occurring compound having a carboxyl group attached to another carbon-containing group (usually $\mathrm{CH}_{2}-$ ) that in turn is considered to an aromatic ring and playing diverse roles in plants such as rooting, cell elongation and flowering (Hartmann et al., 2002). IAA plays fundamental function in coordination of many growth and behavioral processes in the plant life cycle such as rooting of cutting, flowering, aging, root growth, prevention or promotion of stem elongation, color enhancement of fruit and flower etc. (Khan et al., 2007). Honey a preservative solution also used to increase the vase life of cut flowers. It increases the vase life of cut flowers up to 7 days depend upon on the flower crops (Khan, 2015). Sugar and honey as combined solution help in keeping flower fresh and extend its vase life. Sugar with acetic acid increased fresh weight, flower diameter and flower vase life. Keeping in view the effect of these vase solutions on post-harvest attributes of floricultural crops, current study was designed to check the effects of different solutions on vase life and several postharvest attributes of most important cut flowering floricultural crop of Rose (Rosa bybrida cv. Freedom).

\section{Materials and Methods}

Current experiment was performed at Department of Horticultural Sciences, University College of 
Agriculture and Environmental Sciences, The Islamia University of Bahawalpur. Fresh and healthy stems cutting carrying fresh rose flower (Rosa bybrida cv. Freedom) was collected from Rose Garden Research Area of the university. Flowering stem samples were collected early in the morning during cool hours of the day. After brought these flowering stems to lab, these were immediately put under vase solutions which were already prepared. Preservative vase solutions including salicylic acid, Indole-acetic acid and acetic acid was purchased from the commercial scientific store of Bahawalpur. There were 10 treatments in the experiment which were compared with tap water treatment $\left(\mathrm{T}_{0}\right)$. These treatments include $\mathrm{T}_{1}, \mathrm{~T}_{2}, \mathrm{~T}_{3}$, $\mathrm{T}_{4}$ and $\mathrm{T}_{5}$ consisting of honey, sugar, salicylic acid, acetic acid and indole acetic acid respectively. $T_{6}$ to $\mathrm{T}_{9}$ comprises sugar along with all these solutions while $T_{10}$ is combination of all these solutions. Sugar and honey was purchased from the local super store. These vase solutions were prepared in half liter of plastic bottles. All the leaflets were separated from branches which were cut back to a uniform height of 12 inches. All flowering stems were put in the bottles under the prepared vase solutions. There were four flowering stalks in each treatment which were replicated three times. There were 132 flowering stalks in the whole experiment which was arranged according to completely randomized design (CRD). Flowering stalks of all treatment were placed at room temperature $\left(25^{\circ} \mathrm{C}\right)$ with relative humidity of $60-65 \%$.

Plant morphological attributes studied were dry and fresh weight of the flowers $(\mathrm{g})$, flower bud diameter $(\mathrm{mm})$, stem diameter $(\mathrm{mm})$, flower freshness score ( $1^{\text {st }}$ day), flower freshness score ( $3^{\text {rd }}$ day), flower color scoring, petal discoloration scale, market acceptability and vase life. Morphological parameters like fresh weigh and dry weight of the flowering stems were taken by using weighing balance. The weight of cuttings was taken in grams. Dry weight of flowering stems was taken after complete withering of flowers. The flowering stalks were dried in microwave oven at $70^{\circ} \mathrm{C}$ for 48 hours. Flower head diameter and stem diameter was measured by using vernier caliper and the measurements were taken in millimeter $(\mathrm{mm})$. Flower freshness scoring on $1^{\text {st }}$ and $3^{\text {rd }}$ day was calculated on the basis of judgment by judges score 6 for excellently fresh, 4 for medium and 2 for poor freshness (Auger et al., 2007). For $1^{\text {st }}$ day scoring of flower freshness, scoring was done after leaf removal at same day of collection. Flower color scoring was checked after dipping the flowering stems in different preservative solutions. Score 6 for excellent color, 4 for medium and 2 for poor or fade color was calculated. Petal discoloration scale was taken petals start to discolor. Usually petals start to discolor after 4 days. Maximum 8 points was given to flowers with no discolored petal flowers, 6 for discolored petals and 4 for more than 5 discolored petals. Market acceptability was checked after the stem cuttings in different preservative solutions. Market acceptability was checked after 3 days. Vase life was calculated in days which were calculated by freshness of flower its petals start to discolor.

All the recorded data was analyzed by using complete randomized design (CRD) and the treatments were studied by performing analysis of variance (ANOVA) and the means of all the 11 treatments were differentiated according to the least significant difference test (LSD) at 5\% probability level (Steel et al., 1997).

\section{Results and Discussion}

Results indicated statistically significant $(p<0.05)$ effect of different preservative solutions on cut rose flower (Rosa bybrida cv. Freedom) for fresh weight, flower head diameter, flower freshness score, flower color score, petal discoloration scale and market acceptability while non-significant for dry weight, stem diameter, flower freshness score ( $3^{\text {rd }}$ day) and vase life (Table 1 ). The maximum fresh flower weight was recorded in $\mathrm{T}_{0}$ (tap water) with value of $7.50 \mathrm{~g}$ and $\mathrm{T}_{4}$ (acetic acid) with value of $7.50 \mathrm{~g}$. Lowest value was recorded in $\mathrm{T}_{7}$ (sugar + salicylic acid) that were $5.75 \mathrm{~g}$. Other treatments like $\mathrm{T}_{1}$ (honey), $\mathrm{T}_{3}$ (salicylic acid), $\mathrm{T}_{10}$ (sugar + honey + salicylic acid + acetic acid + indole acetic acid and combination of all these treatments), $\mathrm{T}_{8}$ (sugar + acetic acid), $\mathrm{T}_{5}$ (indole acetic acid), $\mathrm{T}_{9}$ (sugar + IAA), $\mathrm{T}_{6}$ (sugar + honey) and $\mathrm{T}_{2}$ (sugar) obtained 7.41, 7.35, 7.31, 7.15, 6.67, 6.42, 6.13 and $6.11 \mathrm{~g}$ fresh flower weight, respectively (Figure 1). Highest flower head diameter $(\mathrm{mm})$ was observed in $\mathrm{T}_{3}$ (salicylic acid) with value of $35.74 \mathrm{~mm}$ followed by IAA $\left(\mathrm{T}_{5}\right)$ with value of $35.23 \mathrm{~mm}$ and $\mathrm{T}_{7}$ (sugar + salicylic acid). Lowest value $20.91 \mathrm{~mm}$ was recorded in $\mathrm{T}_{1}$ (honey). Other treatments like $\mathrm{T}_{4}$ (acetic acid), $\mathrm{T}_{9}$ (sugar + IAA), $\mathrm{T}_{8}$ (sugar + acetic acid), $\mathrm{T}_{6}$ (sugar + honey), $\mathrm{T}_{10}$ (honey + sugar + salicylic acid + acetic acid + indole acetic acid and combination of all these treatments), $\mathrm{T}_{0}$ (tap water) and $\mathrm{T}_{2}$ (sugar) obtained 
$31.59,29.71,29.06,25.25,22.45$ and $22.37 \mathrm{~mm}$ flower head diameter $(\mathrm{mm})$ respectively as shown in Figure 1 .

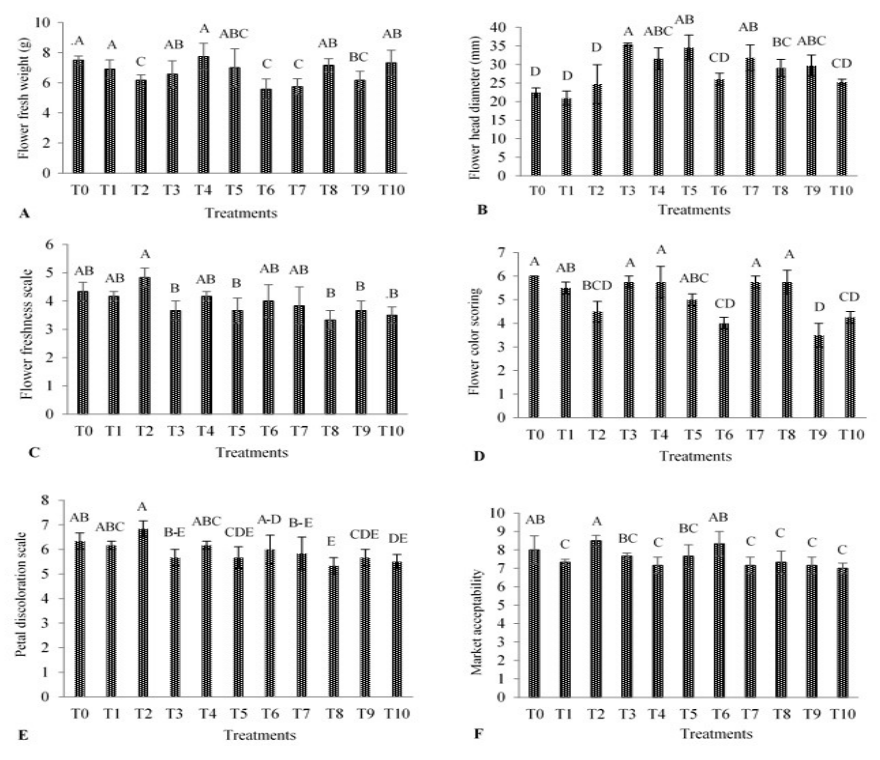

Figure 1: Comparative impact of different preservative solutions on (A) flower fresh weight (g), (B) flower head diameter $(\mathrm{mm}),(\mathbf{C})$ flower freshness, (D) flower color score, (E) petal discoloration scale and (F) market acceptability of Rosa hybrida cv. Freedom. Different letters (A-E) exhibit significant difference among means at $P<0.05$. Each mean consists of 12 samples Vertical bars shows the standard error of the experiment.

Table 1: Sum of squares and mean squares of different postharvest attributes of Rosa hybrida cv. Freedom by different preservative solutions.

$\begin{array}{lll}\text { Parameter } & \text { SS }^{\dagger} & \text { MS }^{+\dagger} \\ \text { Flower fresh weight } & 12.59 & 1.26^{*} \\ \text { Flower head diameter } & 836.16 & 83.62^{*} \\ \text { Flower freshness score } & 9.12 & 0.91^{*} \\ \text { Flower color score } & 22.53 & 2.25^{*} \\ \text { Petal discoloration scale } & 4.52 & 0.45^{*} \\ \text { Market acceptability } & 8.73 & 0.87^{* *}\end{array}$

†SS: Sum of square; †MS: Mean square; "Significant.

The Highest flower freshness scoring was perceived in $T_{2}$ (sugar) with value of 4.50 followed by sugar + honey $\left(\mathrm{T}_{6}\right.$ ) with value of 4.50 and $\mathrm{T}_{0}$ (tap water) with value of 4.30 and $\mathrm{T}_{1}$ (honey) with value of 3.83 . Lowest value 2.95 was observed in $T_{9}$ (sugar + IAA). Other treatments like $\mathrm{T}_{5}$ (IAA), $\mathrm{T}_{3}$ (salicylic acid), $\mathrm{T}_{4}$ (acetic acid), $\mathrm{T}_{8}$ (sugar + acetic acid), $\mathrm{T}_{7}$ (sugar + salicylic acid) and $\mathrm{T}_{10}$ (honey+ sugar + salicylic acid + acetic acid + indole acetic acid and combination of all these treatments obtained 3.70, 3.67, 3.43, 3.50, 3.33 and 3.00 flower freshness scoring respectively as shown in Figure 1. The Highest flower color scoring was observed $\mathrm{T}_{0}$ (tap water) with value of 6.00 followed by $\mathrm{T}_{3}$ (salicylic acid) with value of 5.75 and $\mathrm{T}_{4}$ (acetic acid) with value of 5.75. Lowest value 3.50 was recorded in $\mathrm{T}_{9}$ (sugar + IAA). Other treatments like $\mathrm{T}_{7}$ (sugar + salicylic acid), $\mathrm{T}_{8}$ (sugar + acetic acid), $\mathrm{T}_{1}$ (honey), $\mathrm{T}_{5}$ (IAA), $\mathrm{T}_{2}$ (sugar), $\mathrm{T}_{10}$ (sugar + honey + salicylic acid + acetic acid + IAA and combination of all these treatments) and $\mathrm{T}_{6}$ (sugar + honey) obtained $5.75,5.75,5.50,5.00,4.50,4.25$ and 4.00 flower color scoring respectively as shown in Figure 1.

The highest flower discoloration scale was observed in $T_{2}$ (sugar) with value of 6.62 followed by $T_{0}$ (tap water) with value of 6.33 and $T_{1}$ (honey) with value of 6.17. Lowest value 5.32 was recorded in $\mathrm{T}_{8}$ (sugar + acetic acid). Other treatments like $\mathrm{T}_{4}$ (acetic acid), $\mathrm{T}_{6}$ (sugar + honey), $\mathrm{T}_{7}$ (sugar + salicylic acid), $\mathrm{T}_{3}$ (salicylic acid), $\mathrm{T}_{5}$ (indole acetic acid), $\mathrm{T}_{9}$ (sugar + IAA) and $T_{10}$ (honey + sugar + salicylic acid + acetic acid + indole acetic acid and combination of all these treatments) obtained $6.17,6.00,5.77,5.75,5.67$, 5.67 and 5.49 petal discoloration scale, respectively as shown in Figure 1. Results declared that highest market acceptability was observed $\mathrm{T}_{2}$ (sugar) with value of 8.50 followed by $\mathrm{T}_{6}$ (sugar + honey) with value recorded was 8.31 and $\mathrm{T}_{0}$ (tap water) with value of 8.28. Lowest value was recorded 7.00 of $\mathrm{T}_{10}$ (sugar + honey + salicylic acid + acetic acid and combination of all these treatments). Other treatments like $\mathrm{T}_{5}$ (IAA), $\mathrm{T}_{3}$ (salicylic acid), $\mathrm{T}_{1}$ (honey), $\mathrm{T}_{8}$ (sugar + acetic acid), $\mathrm{T}_{4}$ (acetic acid), $\mathrm{T}_{9}$ (sugar $+\mathrm{IAA}$ ) and $\mathrm{T}_{7}$ (sugar + salicylic acid) showed 7.78, 7.77, 7.33, 7.25, $7.18,7.18$ and 7.14 market acceptability respectively as shown in Figure 1.

Fresh weight of flower is very important character about arbitrating post-harvest attributes of cut flowers crops. Present study showed maximum fresh weight of Rosa bybrida by acetic acid which is parallel with the results of Kazemi et al. (2011) and Chamani et al. (2012) who argued that fresh weight was increases by the addition of acetic acid in the preservative solution. Highest fresh mass of alstromeria flower was received with higher acetic acid concentration which was reported by Chamani et al. (2012). Growth regulators like acetic acid has direct effect of mechanism of plant metabolism and results also showed that acetic acid has beneficial effect on minerals and water transport in plants and especially necessary for the availability and transportation of micronutrients in different cut flowers (Ansari et al., 2011). Flower head diameter 
results were similar with the findings of Ezhilmathi et al. (2007) and Hajizadeh and Aliloo (2014) who concluded salicylic acid increases the flower diameter in tuberose and gladiolus. Similar effects were also noted by Kazemi et al. (2011) who declared that salicylic acid, citric acid and ascorbic acid on flower quality and floret diameter of different cut flower crops. Improved flower diameter was might be due to role of SA in plants physiological and biological processes (Hayat et al., 2009) as it reduces the ACC synthesis and suppresses the oxidation process in different cut flower floricultural crops. A combined solution of sucrose $+\mathrm{SA}$ is also recommended to enhance the post-harvest attributes drastically (Gerailoo and Ghasemnezhad, 2011). Flower freshness scoring results were driven in accordance with the researches of El-Tayeb (2005) and Gunes et al. (2007) who noted that (sugar) sucrose-treated plants had been experienced to have good chlorophyll contents which ultimately relates to fresh appearance of the flowers. Similar findings were also observed by Shirin and Mohsin (2011) who believe on freshness of flowers were highly improved by sugar as vase solution but current is study also contradictory with the results of Shirin and Mohsin (2011) who argued that sugar combination with other chemical preservatives improved flower freshness which totally opposite with the current study. Recent researches showed that appearance (color) of flowers was enhanced by salicylic acid as elaborated by Xueping et al. (1999) who stated that the appearance of cut rose flowers was enhanced positively after treating with salicylic acid. Similar conclusions were also obtained by Xueping et al. (1999) concluded that different concentrations of salicylic acid made cut flowers more colorful and attractive than all other treatments. These results were also in line with the conclusion of Iqbal et al. (2012) who stated that due to growth regulators (acetic acid), flower physical appearance remains more charming and appealing for longer period of time that untreated treatments. During current experiment, petal discoloration score was less than 2.0 which was due to salicylic acid used in the vase solution. It may be due to higher / lower contents of salicylic acid in the solution. In the vase solution salicylic acid acts as germicide and sugar supplies the carbohydrates to cut flowers. Addition of sugar to the vase solution helps to controls the displeasing reactions like loss of petals color (Susan, 2003). Similar results according to current study were also noted by Mehraj et al. (2013) with highest petal discoloration score with different concentration of carbohydrates. Results have indicated that quality of several cut flowers is affected positively by using salicylic acid, citric acid and ascorbic acid. There might be another reason due to cultivar effect as the performance of different germplasm is different in the similar environmental conditions (Kazemi et al., 2011). Therefore, salicylic acid was used to enhance the vase life and market acceptability of cut rose flowers and positive results were obtained. Different concentrations of sugar increases petal water contents resulting more freshness of flowers with high market acceptability was also obtained by Vahdati et al. (2012).

\section{Conclusions and Recommendations}

Sugar is an ideal preservative solution for Rosa bybrida cv. Freedom as it improves post-harvest characteristics in this study. Sugar $\left(\mathrm{T}_{2}\right)$ recommended as best preservative solution for flower freshness and acceptability by consumer in the flower market. It is, therefore concluded that sugar solution must be considered for experiment where other cut flowering crops are under research trials for the improvement of new post-harvest attributes and vase life.

\section{Novelty Statement}

Sugar is ideal vase life solution for improving flower quality and market acceptability of Rosa bybrida $\mathrm{Cv}$. Freedom. It is worth to note that sugar must be applied independently (not mix with any other acidic solution) for better results and further research on other cut flowers should be under consideration for enhancement of post-harvest attributes.

\section{Author's Contribution}

Muhammad Ahsan: Conceived the idea.

Aneela Ramzan: Wrote methodology and collect data.

Muhammad Nafees: Wrote result and discussion.

Adnan Younis: Technical Input at every step.

Muhammad Amin: Data entry.

Gulzar Akhtar: Wrote abstract.

Khansa Saleem: Collected data.

Azka Sabeeh: Worked on references.

\section{Conflict of interest}

The authors have declared no conflict of interest. 
References

Ahsan, M., A. Riaz, M.J. Jaskani and M. Hameed. 2017. Physiological and anatomical response of fragrant Rosa species with treated and untreated wastewater. Int. J. Agric. Biol., 19: 13-22. https://doi.org/10.17957/IJAB/15.0160

Ansari, S.,E.Hadavi,M. Salehi and P.Moradi.2011. Application of micro-organisms compared with nanoparticles of silver, humic acid and gibberellic acid on vase life of cut gerbera good timing. J. Orn. Hort. Plant, 1(1): 27-33.

Auger, P., T.M. Devinney and J.J. Louviere. 2007. Using best-worst scaling methodology to investigate consumer ethical beliefs across countries.J. Bus. Ethics, 70(3): 299-326. https:// doi.org/10.1007/s10551-006-9112-7

Bayat, H., R. Geimadil and A.A. Saadabad. 2013. Treatment with essential oils extends the vase life of cut flowers of lisianthus (Eustoma grandiflorum). J. Med. Plant By-Prod., 2: 163169.

Butt, S.J., 2005. Extending the vase life of roses (Rosa bybrida) with different preservatives. Int. J. Agric. Biol., 7: 91-99.

Chamani, E., B. Esmaeilpour, Y. Poorbeiramihir, H. Malekilajayer and A.Saadati.2012.Investigation the effects of thidiazouron and humic acid on postharvest life of cut Alstroemeria aurantifolia cv. "Konyambe". J. Hortic. Sci., 26(2): 147-152.

Elgimabi, M.E.N.E., 2011. Vase life extension of rose cut flowers (Rosa bybirida) as influenced by silver nitrate and sucrose pulsing. J. Agric. Biol. Sci., 6(1): 128-133. https://doi.org/10.3844/ ajabssp.2011.128.133

El-Tayeb, M.A., 2005. Response of barley grains to the interactive effect of salinity and salicylic Acid. Plant Growth Regul., 45: 215-225. https://doi.org/10.1007/s10725-005-4928-1

Ezhilmathi K., V. Singh, A. Arora and R. Sairam. 2007. Effect of 5-sulfosalicylic acid on antioxidant activity in relation to vase life of Gladiolus cut flowers. Plant Growth Regul., 51: 99-108. https://doi.org/10.1007/s10725-006$9142-2$

Fanourakisa, D., R. Pieruscchka, A.J. Savvides, Macnish, V. Sarlikioti and E.J. Woltering. 2013. Sources of vase life variation in cut roses.A review. Postharvest Biol. Technol., 78: 1-15. https:// doi.org/10.1016/j.postharvbio.2012.12.001

Fariba, R., H. Davood and H.V. Shokrollah.
2012. Effect of salicylic acid on vase life of cut carnation (Dianthus caryophyllus L. cv. 'Liberty Abgr'). Ann. Biol. Res., 3(11): 5127-5129.

Gerailoo, S. and M. Ghasemnezhad. 2011. Effect of salicylic acid on antioxidant enzyme activity and petal senescence in Yellow Island cut rose flowers. J. Fruit Ornam. Plant Res., 19(1): 183193.

Gunes, A., A. Inal, M. Alpaslan, F. Eraslan, E.G. Bagci and N. Cicek. 2007. Salicylic acid induced changes on some physiological parameters symptomatic for oxidative stress and mineral nutrition in maize (Zea mays L.) grown under salinity. J. Plant Physiol., 164: 728-736. https:// doi.org/10.1016/j.jplph.2005.12.009

Hajizadeh, H.S. and A.A. Aliloo. 2014. Postharvest quality studies in tuberose (Polianthes tuberosa cv. Perri) cut flowers as affected by vase preservative solutions. Int. J. Agric. Innov. Res., 2(6): 895-899.

Hartmann,H.T., Kester, D.E., Davies, F.T. and R.L. Geneve. 2002. Plant propagation principles and practices. $7^{\text {th }}$ Edition. Prentice Hall. New Jersey, pp. 367-374.

Hayat, Q. S. Hayat, M. Irfan and A. Ahmad. 2009. Effect of exogenous salicylic acid under changing environment: A review. Environ. Exp. Bot., 68: 14-25. https://doi.org/10.1016/j. envexpbot.2009.08.005

He, S., D.C. Joyce, D.E. Irving and J.D. Faragher. 2006. Stem and blockage in cut Grevillea 'Crimson Yul-lo' inflorescences. Postharvest Biol. Technol., 41: 7-84. https://doi. org/10.1016/j.postharvbio.2006.03.002

Iqbal, D., U. Habib1, N.A. Abbasi and A.N. Chaudhry. 2012. Improvement in postharvest attributes of zinnia (Zinnia elegans cv. benary's giant) cut-flowers by the application of various growth regulators. Pak. J. Bot., 44(3): 10911094.

Kazemi M, E. Hadavi, and J. Hekmati. 2011. Role of salicylic acid in decreases of membrane senescence in cut carnation flowers. J. Agric. Sci. Technol., 7: 1417-1425.

Khan, P., S. Shahrin, T. Taufique, H. Mehraj and A.F.M.J. Uddin. 2015. Prolonging vase life of cut rose (Rosa bybrida L. cv. Red Pearl) through chemical preservatives. J. Biosci. Agric. Res., 5(1): 10-15. https://doi.org/10.18801/ jbar.050115.49

Khan, R.U., M.S. Khan, A. Rashid and MA. Farooq. 
2007. Effect of exogenous Indole-3-acetic acid and naphthalene acetic acid on regeneration of damask rose cuttings in three growing media. Pak. J. Biol. Sci., 10(20): 3626-3631. https:// doi.org/10.3923/pjbs.2007.3626.3631

Loubaud, M. and W.G. Van. 2004. Wound induced and bacteria induced xylem blockage in rose Astilbe and Viburunm. Postharvest Biol. Technol., 32: 281-288. https://doi. org/10.1016/j.postharvbio.2003.12.004

Mehraj, H., A.F. Ona, T. Taufique, M.Z.K. Roni and A.F.M.J. Uddin. 2013. Vase life of cut rose (Rosa Hybrida L.) against easy to ready up different available solution. Int. J. Sustain Agric. Technol., 9(3): 29-34.

Morris, K., S.A. Makerness, T. Page, C.F. John, A.M. Murphy, J.P. Car and V.B. Wollaston. 2000. Salicylic acid had a role in regulating gene expressions during leaf senescence. J. Plants, 23: 677-685. https://doi.org/10.1046/j.1365313x.2000.00836.x

Nikbakht, A., M. Kafi, M. Babalar, Y.P. Xia, A. Luo and N. Etemadi. 2008. Effect of humic acid on plant growth, nutrient uptake and postharvest life of Gerbera. J. Plant Nutr., 31: 155-2167. https://doi.org/10.1080/01904160802462819

Raskin, I., 1992. Role of salicylic acid in plants. Annu. Rev. Plant Physiol. Plant Molecul. Biol., 43: 439-463. https://doi.org/10.1146/annurev. pp.43.060192.002255

Raskin, I., H. Skubatz, W.Tang and B.J.D. Meeuse. 1990. Salicylic acid levels in thermogenicand non-thermogenic plants. Ann. Bot., 66: 376383. https://doi.org/10.1093/oxfordjournals. aob.a088037

Sariot, V., R. Paradiso, H. Rogers and S. De Pascale. 2014. Ethylene control in cut flowers: Classical and innovative approaches. Postharvest Biol. Technol., 97: 83-92. https://doi.org/10.1016/j. postharvbio.2014.06.010

Shakirova, M.F., A.R. Sakhabutdinova, M.V. Bezrukova, R.A. Fatkhutdinova and D.R. Fatkhutdinova. 2003. Changes in the hormonal status of wheat seedlings induced by salicylic acid and salinity. Plant Sci., 164(3):317-322. https:// doi.org/10.1016/S0168-9452(02)00415-6

Shirin, R. and O.Mohsen. 2011. Effect of chemical treatments and sucrose on vase life of three cut rose cultivars. J. Res. Agric. Sci., 7(2): 133-139.

Steel, R.G.D., J.H. Terrie and D.A Dicky. 1997. Principles and procedures of statistics: $3^{\text {rd }} \mathrm{Ed}$. McGraw-Hill, New York.

Susan, S.H., 2003. Role of sugar in the vase solution on post-harvest flower and leaf quality of oriental lily 'Stargazer'. HortScience, 38(3): 412-416. https://doi.org/10.21273/HORTSCI.38.3.412

Susan, S.H., 2003. Role of sugar in the vase solution on post-harvest flower and leaf quality of three cut rose cultivars. J. Res. Agric. Sci., 7(2): 214219.

Vahdati, M.N., A. Tehranifar, H. Bayat and Y. Selahvarzi. 2012. Salicylic and citric acid treatments improve the vase life of cut chrysanthemum flowers. J. Agric. Sci. Technol., 14: 879-887.

Van Doorn, W.G., 1997. Abscission of flowers and floral parts. J. Exp. Bot., 488: 821-837. https:// doi.org/10.1093/jxb/48.4.821

Van Leperen, W., 2007. Ion- mediated changes of xylem hydraulic resistance in plant a fact or fiction? Trend Plant Sci., 12: 137-142. https:// doi.org/10.1016/j.tplants.2007.03.001

Van Meeteren, U., V.H. Gelder and V. Ieperen. 2000. Reconsideration of the use of deionized water as water in post-harvest experiments on cut flowers. Postharvest Biol. Technol., 18: 169-181. https://doi.org/10.1016/S09255214(00)00074-0

Williamson, V.G., J.D. Faragher, S. Parsons and P. Franz. 2002. Inhibiting the postharvest wound response in wild flowers. Rural Ind. Res. Dev. Corp, 2(114): 23-29.

Xueping, L., P. Xuequn, Z. Zbaoqi and L. Zuoliang. 1999. Preservation effects of salicylic acid on cut roses. J. Fujian Acad. Agric. Sci., 14: 38-42.

Younis, A., A. Riaz, S. Aslam, M. Ahsan, U. Tariq, F. Javaid, M. Nadeem and M. Hameed. 2013. Effect of different pruning dates on growth and flowering of Rosa centifolia. Pak. J. Agri. Sci., 50: 605-609.

Zencirkiran,M.,2010.Effect of 1-MCP (1- Methyl Cyclopropene) and STS (Silver thiosulphate) on vase life of carnation. Int. J. Agri. Res., 5(1):112-117. 